\title{
Stanza, Rhyme and Metre in Nineteenth-Century Byelorussian Verse. Some Statistical Observations
}

\author{
BY
}

\author{
ARNOLD B. McMILLIN
}

The nineteenth century is an important period in the history of Byelorussian versification for it saw a number of major evolutionary changes: from the syllabic verse which, partly under Czech and Polish influence, had flourished in the late mediaeval period, to syllabo-tonic patterns and finally, in Bahuševič and his contemporaries, the tonic verse which was to find its ultimate justification as the foundation for Bahdanovič's vierš biełaruskaha składu. The study of Byelorussian versification is still in its infancy and has hitherto tended to suffer from an imprecise approach based on impression rather than detailed factual analysis. ${ }^{1}$ This is particularly true of the 19 th and early 20th centuries where the strong influence of folk poetics on many works make it difficult to apply normal criteria or use conventional descriptive terminology without a considerable element of artificiality.

The present study aims to use statistical and other factual material to make this complex and elusive subject less ambiguous. Table 1 shows, for convenience, the 19th-century writers and poetical texts in approximately chronological order, together with abbreviations where these are used in the statistical tables. Table 2 lists in alphabetical order the poems (with abbreviations) for which dates are unknown and difficult to surmise from internal or external evidence. ${ }^{2}$ Asterisked writers and texts in Tables 1-2 are those which are not subsequently mentioned in this study: all belong to the group of 29 poems with no regular or classifiable metre. ${ }^{3}$

1. Two recent studies, however, show signs of deeper research and scholarship: I. D. Ralko, Biełaruski vierš. Staronki historyi $i$ teoryi, Minsk, 1969, and M. M. Hrynčyk, Šlachi biełaruskaha vieršaskładañnia, Minsk, 1973. Both are reviewed in The Journal of Byelorussian Studies, II, 2, p. 241, and the present issue, respectively.

2. For more detailed information regarding dates of composition and publication the reader is referred to the bibliography in the present author's 'A Conspectus and Bibliography of Byelorussian Literature in the Nine'teenth Century', The Journal of Byelorussian Studies, II, 3, London, 1971, pp. 27188 , upon which this study is based.

3. See below. 


\section{TABLE 1}

\section{POETS AND ANONYMOUS POEMS IN APPROXIMATELY CHRONOLOGICAL ORDER}

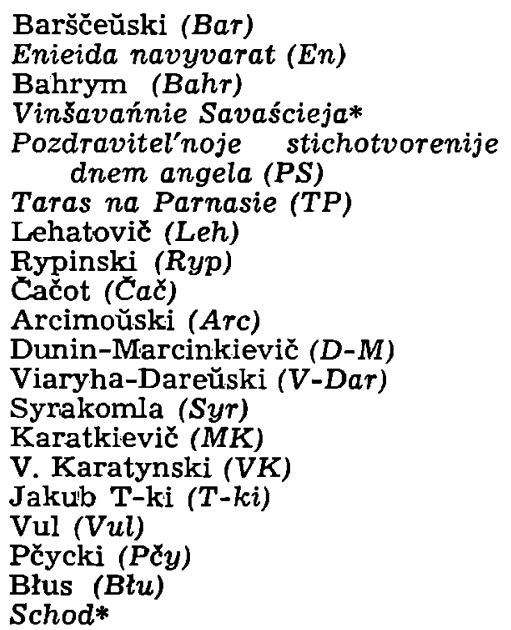

Vinšavańnie Savaścieja*

Hutarka Danity sa Sciapanam (HDsaS)

Hutarka dvuch susiedaŭ (HDS)

Hutarka staraha dzieda (HSD)

Pieśn na božy čas*

so

Savič (Sav)

Savič-Zabłocki $(S-Z)$

Pratasievič (Pr)

Hutarka ŭ karčmie (HŭK)

Horevid (Hor)

Jelski (Jel)

Mihanovič (Mih)

Bahuševič (Bahu)

Hurynovič (Hur)

Łučyna (Łuč)

Tapčeŭski (Tap)

Šunkievič (Šun)

Tamaševič (Tam)

Viten-Dubiejkaŭski (V-Dub)

Staŭbun (Staŭ)

Abuchovič ( $A b u)$

\section{TABLE 2}

\section{UNDATED POEMS}

\section{Chimka z Hankaju*}

\section{Dudar*}

Hej, kab nam być viesialej (HKN)

Hutarka Kuźmy z Apanasam (HKA)

Hutarka Paǔluka (HP)

B. Karatynski, Chto našaj mužyckaj movaj (BK)

K-ko, Mahitki (K-ko)

Matadzikova hutarka (MH)

N. F., Nočču ŭ siale (N. F.)

Nove $j$ šije stichi (NS)

Oj, viaśnica, viasna*

\author{
$P a d d u d u(P d)$ \\ Panskaja taska (Pモ) \\ Pračystaja siarod nočy (PSN) \\ Razmova pana $z$ chtopam* \\ Stary Vosip baradaty (SVB) \\ Tatur, Pradki (Tat) \\ Teatr* \\ Viasna hola pierapala (VHP) \\ Voś ciapier jaki lud staŭ (VCJ) \\ Vos vidzicie vy, dzieci* \\ Ziamielka maja $(\mathrm{Zm})$
}

Stanzas are perhaps the least studied aspect of Byelorussian versification, although in the opinion of some commentators they 'demonstrate the general level of a country's poetic culture'." However, of the 223 poems (totalling 21,042 lines) which comprise 19th-century Byelorussian poetry ${ }^{5}$ only $99(44.4 \%)$ have any kind of regular stanza. Of these, 73 are completely regular, 9 have 2 different types of stanza, 8 have more than 2 types, and 9 are only partially divided strophically. Of the 73 poems with completely regular stanzas $59(80.8 \%)$ consist of quatrains; there are also 6 with stanzas of 5 lines, 3 with 8 , and 1 poem with regular 10 -line stanzas. ${ }^{6}$ It is

4. See, for example, M. M. Hrynčyk, op. cit., pp. 18-19.

5. Statistics relating to Byelorussian literature are still to some extent fluid, as from time to time discoveries of lost works continue to be made.

6. Hurynovič's Himn (Viečny revalucyjanier), a translation from the Ukrainian of Ivan Franko which preserves the metre, stanza formation and rhyme scheme (abbaccddee) of the original. 
perhaps not surprising that of the 59 poems with regular quatrains just under half (29) have alternate rhymes (abab), traditionally the most common rhyme scheme for quatrains in the poetry of many countries. ${ }^{7}$ The figures for the remaining rhyme schemes (17 couplets (aabb), $11 a b c b, 1$ a mixture of $a a b b$ and $a b a b$, and $1 a b a b$ caca dada $)^{8}$ are swollen by Cačot's Pieśni: $12 a a b b$ and $9 a b c b$. Without Cačot's poems the proportion of regular quatrains with the rhyme scheme $a b a b$ would be considerably higher $(74.4 \%)$.

Of all the 73 poems with completely regular stanzas $30(41.1 \%)$ have the rhyme scheme $a b a b, 22(30.1 \%) a a b b, 11(15.6 \%) a b c b$, $1(1.4 \%)$ a mixture of $a a b b$ and $a b a b$, and $9(12.3 \%)$ do not conform to any of these schemes. That there are only 9 such poems perhaps reflects in part the general lack of strophic development in 19thcentury Byelorussian poetry. Apart from the Hurynovic translation and Viaryha-Dareŭski poem already mentioned, they comprise the following: Hurynovič's translation from Kasprowicz, Viasna ('Zdrastvuj, krasnaja viasna...' - abacdbcd; Horevid's Ja kliču Vas abccba; Barščeŭski's Ach, čym ža tvaja, dzievańka, hałoŭka zaniata? - aabbc; Bahuševič's Durny mužyk, jak varona - 6 x aabbccrr, 1 x aabcbcrr; and finally 3 of Cačot's Pieśni - aabbr.

Of the 9 poems with 2 types of stanza 8 simply represent the introduction of 1 different stanza into an otherwise regular pattern: for example, Bahrym's Zajhraj, zajhraj, chłopča mały ends with a 5-line stanza rather than a quatrain. More interesting is Łučyna's Busiet which alternates 5-line stanzas with quatrains (abaab cdcd). The 8 poems with mixed stanzas include 3 of Dunin-Marcinkievič's works: Hapon (quatrains and 6-, 8- and 12-line stanzas), Vierš Nauma Pryhavorki (quatrains and 6- and 8-line stanzas) and Bylicy, raskazy Nauma (up to 12 lines, but with a preponderance of quatrains). The first of Błus's verse tracts Reč ${ }^{\prime}$ starovojta krest'janam o svobode (dlja narodnogo čtenija) has quatrains and 6- and 8-line stanzas, the latter predominating, whilst its sequel Reč starovojta (dlja čtenija moim zemljakam) has a variety of different stanzas, largely unorganised, ranging from 4 to 12 lines in length. Bahuševič's Maja chata has quatrains and 6- and 8-line stanzas, whilst the anonymous Pozdravitel'noje stichotvorenije so dnem angela has 7 stanzas of 10 lines, and 1 each of 11 and 13 lines. The semantically divided sections of Taras na Parnasie (16 to 32 lines in length) can hardly be described as stanzas.

The 9 poems which are only partially divided into stanzas comprise 2 of Cačot's philomath poems - from Jeżowe (quatrains and 6-line stanzas) and from Adamowe $i$ Tomaszowe (quatrains), and the following of Dunin-Marcinkievič's works: Pavinšavañnie Vojta Nauma (6- and 8-line stanzas), Viečarnicy (couplets, quatrains and 6- and 8-line stanzas), Kupała (quatrains and 6- and 8-line stanzas), Chalimon na karanacyi (as Kupała), Ščaroǔskija dažynki (as Kupała), Travica brat-siastryca (as Kupała), and Pinskaja šlachta (couplets, quatrains and 6- and 8-line stanzas).

7. See, for example, B. O. Unbegaun, Russian Versification, Oxford, 1956, p. 74.

8. Viaryha-Dareŭski's Adaśka, rodny Adaśka. 
Finally, the number of works with strophic division may be shown as a proportion of the six leading poets' total opus: Cačot $93.7 \%$, Dunin-Marcinkievič $83.3 \%$, Bahuševič $27.9 \%$, Hurynovič $29.2 \%$, Łučyna $72.2 \%$, and Tapčeǔski $80.0 \%$. Taken together their average $(63.0 \%)$ is notably higher than the equivalent percentage for the century as a whole $(44.4 \%)$.

A feature relating to the folk inspiration behind much of 19thcentury Byelorussian poetry is the use of a refrain at the end of 9 of the poems ( 4 of Cačot, 2 of Bahuševič, 2 of Łučyna and 1 of Tatur), usually in the form of 1 or 2 lines repeated in each verse; Eučyna's Nadta sałodkija dumki repeats the last 2 lines of alternate (even) stanzas. Other types of repetition are also found, but with less regularity: Horevid's $J a$ kliču Vas opens each stanza with the same phrase, Čačot's Kab u karčmie nie siadzieŭ repeats the opening line (in 3 out of 4 stanzas), and in each stanza of Hurynovič's Viasna (see above) the 3 rd line repeats the 1 st, and the 7 th line repeats the 5 th, with only a slight variation of the 7 th line in the 1 st and last stanzas.

The figures for the rhyme schemes of the 73 poems with regular stanzas (see above) may be compared with those for all the 223 poems under consideration: $74\left(33.2^{\%} \%\right)$ aabb, $63(28.3 \%) a b a b, 34(15.2 \%)$ mixed $a a b b$ and $a b a b, 10(4.0 \%) a b c b, 2(0.9 \%) a a b b$ and $a b b a$, and $5(2.2 \%) a a b b, a b a b$ and $a b b a$; the remaining 35 poems have irregular or inconsistent rhyme schemes, but include 19 that are basically aabb, 7 basically $a b a b, 5$ mixed $a a b b$ and $a b a b$, and 4 that are without rhyme. ${ }^{9}$ If these figures are added to those for verses with consistent rhyme schemes the proportions are as follows: $42.1 \%$ aabb, $31.4 \%$ $a b a b$, and $2.2 \%$ mixed $a a b b$ and $a b a b$.

Table 3 shows the number of poems with the 6 main rhyme schemes (including irregular elements) in the work of the leading poets. The bracketed numbers show the preceding figure as a percentage of the writer's total verse output.

\section{TABLE 3}

THE RELATIVE INCIDENCE OF PRINCIPAL RHYME SCHEMES

$a a b b \% a b a b \% a a b b \& a b a b \% a b c b \% a a b b \& a b b a \% a a b b, a b a b \& a b b a \%$

$D-M \quad 1(8.3) \quad 0 \quad(0.0)$

Bahu 10(23.2) 22(51.2)

Hur $\quad 7(29.2) \quad 12(50.0)$

Łuč 6(33.3) 10(55.5)

$\begin{array}{lll}\text { Tap } & 1(20.0) & 4(80.0)\end{array}$

\begin{tabular}{|c|c|c|}
\hline & (6.2) & $10(31.2)$ \\
\hline & $(33.3)$ & $0(0.0$ \\
\hline & $(25.6)$ & $0(0.0)$ \\
\hline & $(20.8)$ & $0(0.0$ \\
\hline & (11.1) & $v$ \\
\hline & $(0.0)$ & 0 \\
\hline
\end{tabular}

0

2

0

0

0

0
(0.0)

(16.6)

$(0.0)$

$(0.0)$

$(0.0)$

(0.0)
0

5

0

0

0

(41.6)

$(0.0)$

It is noticeable that in the work of these poets (with the exception of Cačot) plain couplets (aabb) form a smaller proportion of the total than they do in the average for the century as a whole which includes a considerable number of anonymous verses, many of them folkbased, for which rhyming couplets are the principal organising factor. The limitation of combinations involving enclosing rhyme (abba) to one writer, Dunin-Marcinkievič, is to some extent a reflection of the latter's comparatively great interest in stanza and rhyme. None of

9. Horki p'janica, $P^{\prime} j a n i c a$, Sto ja kamu vinavat? and Łavryja from Novejšije stichi in Je. R. Romanov, Belorusskij sbornik, I, 5, Viciebsk, 1891, pp. 431-7. 
his strophically divided poems ${ }^{10}$ employs less than 2 types of stanza and rhyme scheme, and many (Hapon, for example) contain great variations within the compass of one poem. A particularly characteristic stanza of Dunin-Marcinkievič is the 6-line aabccb which occurs in Hapon, Viečarnicy, Kupała, Chalimon na karanacyi, Ščroǔskija dažynki and Travica brat-siastryca.

Three types of rhyme, masculine, feminine, and dactylic, are found in Byelorussian 19th-century verse. Most frequently met is a combination of masculine and feminine, accounting for $65.0 \%$ of the total number of poems considered; exclusively feminine represents $25.6 \%$, and exclusively masculine $4.9 \%$.

Table 4 shows the number of poems with these types of rhyme in the work of the leading poets. The bracketed numbers show the preceding figure as a percentage of the writer's total verse output.

TABLE 4

THE RELATIVE INCIDENCE OF PRINCIPAL RHYME TYPES

\begin{tabular}{|c|c|c|c|c|c|c|}
\hline & $M F$ & $11 \%$ & $F$ & $0 \%$ & $M$ & $\%$ \\
\hline$\check{C} a \check{c}$ & 18 & (56.2) & & $(28.1)$ & 3 & (9.4 \\
\hline$D-M$ & 10 & $(84.6)$ & 2 & (15.4) & 0 & \\
\hline Bahu & 26 & $(60.5)$ & 14 & (32.4) & 1 & (2 \\
\hline Hur & 12 & $(50.0)$ & 7 & $(29.1)$ & 4 & (16. \\
\hline Łuč & 3 & (16.6) & 12 & (66.6) & 1 & 1 \\
\hline Tap & 4 & $(80.0)$ & 1 & $(20.0)$ & 0 & (0. \\
\hline
\end{tabular}

No poem consists entirely of dactylic rhymes, but 8 verses contain dactylic rhymes in various combinations with the other two types. Łučyna's Rodnaj staroncy and Usioj trupie dabradzieja Staryckaha biełaruskaje stova combine dactylic and feminine rhymes in roughly equal proportions, and Hurynovič's Bor has alternate masculine and dactylic rhymes. Cačot's $A$ maja $\breve{z}$ kvietačka opens with 4 lines of dactylic rhyme, and his Nie na toje Boh stvaryŭ ends each stanza with a dactylic couplet refrain; in both poems the remaining lines have masculine rhyme. In Bahuševič's Smyk there is 1 dactylic rhyme inserted in a poem consisting otherwise of masculine rhymes, and in the anonymous Ziamielka maja only the 2nd line has a dactylic ending, the remainder being masculine and feminine. Lastly, Bahuševič's translation from Krylov, Svińnia $i$ žatudy, has 1 dactylic rhyme in addition to 4 feminine and 3 masculine. A popular combination of rhyme scheme and type is MFMFabab, accounting for $20.1 \%$ of all the 19th-century poems, and, in particular, $30.2 \%$ of Bahuševič's, $33.3 \%$ of Hurynovič's, and $60.0 \%$ of Tapčeŭski's poems.

Finally, mention must be made of the Leonine verse pattern that is found in some 10 of the 19th-century poems: Cačot's Jak to dobra, kali mužyk and Oj čamu ty zazulačka, Arcimoŭski's Pani Tvardoŭskaja, Bahuševič's Udava and Panskaja łaska, Hurynovič's Viesialčak, and

10. Only the translation of Pan Tadeusz, and the short verse Zaŭtra spasa, kažuć ludzie are not divided into stanzas.

11. The $M F$ group includes a number of poems where although the rhymes are mixed one type predominates. Principally $F$ : Cačot 4; Dunin-Marcinkievič 3; Bahuševič 4; Hurynovič 1 . Principally $M$ : Cačot 3; Bahuševič 1; Tapčeŭski 1. 
Łučyna's Nadta sałodkija dumki, Pahudka, Sto ptuški kazali and Viasnovaj paroj. Leonine elements are also found in 2 of Barščeŭski's verses, Ach, čym ža tvaja, dzievańka, hałoŭka zaniata? and Harelica, although they are not fully developed. ${ }^{12}$ Hrynčyk is inclined to regard these elements in Barščeŭski and in Łučyna's Pahudka as linked with Polish traditions, but in the latter writer's Viasnovaj paroj, as in Bahuševič's Panskaja łaska and the poems of Kupała and Kołas, as related to the Ukrainian kolomyjka and folk traditions. ${ }^{13}$

The influence of folk metre and rhythms on much of 19th-century Byelorussian verse makes it impossible to categorise with even the modest degree of accuracy that prosodists dealing with more 'literary' poetry may hope to achieve. ${ }^{14}$ In attempting to label recalcitrant material the present writer has adopted a more conservative approach than his immediate predecessors, which in part explains the large number of poems which are not felt to fit into any 'established' category. The 223 poems under consideration may be divided into four main groups, each of which is capable of further subdivision: strict syllabic ${ }^{15} 40(17.9 \%)$, syllabo-tonic $37(16.6 \%)$, tonic $31(13.9 \%$ ), and miscellaneous (i.e. poems not clearly fitting one of the first three categories) $115(51.6 \%)$. Table 5 shows the number of works by each of the 10 principal poets falling into the 4 main groups. The bracketed numbers show the preceding figure as a percentage of the whole.

\section{TABLE 5}

THE TYPES OF VERSE USED BY THE PRINCIPAL WRITERS

\begin{tabular}{|c|c|c|c|c|c|}
\hline \multicolumn{2}{|r|}{ Syllabic \% 0} & Syllabo-tonic $\%$ & Tonic $\%$ & \multicolumn{2}{|c|}{ Miscellaneous $\%$} \\
\hline$a_{r}$ & $\begin{array}{ll}0 & (0.0)\end{array}$ & $(0.0)$ & $\begin{array}{ll}0 & (0.0)\end{array}$ & 3 & $(100.0)$ \\
\hline & $9(28.1)$ & (3.1) & $\begin{array}{ll}0 & (0.0)\end{array}$ & 22 & $(68.7)$ \\
\hline$-M$ & $4(33.3)$ & $(0.0)$ & $(0.0)$ & 8 & (66.7) \\
\hline $2 r$ & 1 (33.3) & $(0.0)$ & $\begin{array}{ll}0 & (0.0)\end{array}$ & 2 & (66.7) \\
\hline$a n$ & $6(13.9)$ & $6 \quad(13.9)$ & $19(44$ & 12 & (27.9) \\
\hline & $5(20$. & $7 \quad(29$ & $7(29$ & 5 & (20.8) \\
\hline & $9(50.0)$ & $4 \quad(22.2)$ & 3 (16.7) & 2 & (11.1) \\
\hline & $1(20$. & $4 \quad(80$. & $0 \quad(0$ & 0 & $(0.0)$ \\
\hline$J$ & $1(25.0)$ & $(0$ & $(0.0)$ & 3 & (75.0) \\
\hline$b u$ & $\begin{array}{ll}0 & (0.0)\end{array}$ & $4(100.0)$ & $\begin{array}{ll}0 & (0.0)\end{array}$ & 0 & $(0.0)$ \\
\hline
\end{tabular}

12. Ralko also sees $8 / 6$ Leonine elements in some of Dunin-Marcinkievič's works, although here, as in Barščeǔski, they are kept in long (14-syllable) lines rather than broken. I. D. Ralko, op. cit., p. 105. A case in point would seem to be Vierš Nauma Pryhavorki.

13. It is curious, however, that he also sees in Barščeŭski's 'Leonine' poems a slight approach to a tonic basis. M. M. Hrynčyk, op. cit., pp. 78, 143, 192-3, 208 and 223.

14. The question of popular or folk versification is itself a still underresearched subject, so that whilst many writers (Barščeǔski, Cačot and Dunin-Marcinkievič in the early part of the century or Hurynovič, Tapčŭski and Abuchovič at the end of it, for example) sought to fuse literary and popular elements in their poetry, it is often difficult to come to precise conclusions about the resulting hybrid forms.

15. The term 'strict syllabic' refers to verses whose lines fulfil three conditions: a fixed number of syllables, exclusively feminine rhyme and a regular caesura where appropria'te (i.e. in the longer lines). 
The relationship between the number of Dunin-Marcinkievič's regular syllabic verses and his 'irregular' works reflects his not entirely successful attempts to adapt the syllabic system of versification to what he saw as specifically Byelorussian needs, by increasing the importance of tonic elements in his still basically syllabic verse. A comparison of his Polish and Byelorussian poems reveals the latter to be much freer. It is interesting that poems in strict syllabic metre continued to be written throughout the century even by writers like Bahuševič, Hurynovič and Łučyna who were at the same time seeking characteristically Byelorussian forms. The figures clearly reflect the experimental nature of these three poets' work, and in particular the role of Bahuševič in developing Byelorussian tonic verse, both in 2-stress lines with their close links with folkintonational poetry, and in 4-stress lines, often with an undeveloped amphibrachic cadence, which probably had their origin in 12- and 13-syllable Polish verse (see Table 11 below).

Table 6 shows the number of poems with strict syllabic verse arranged according to the different measures.

TABLE 6

THE INCIDENCE OF SYLLABIC VERSE

\begin{tabular}{|c|c|c|c|}
\hline \multirow{2}{*}{\multicolumn{2}{|c|}{$\begin{array}{l}6 \text { syllables } \\
8\end{array}$}} & & $6(15.0)$ \\
\hline & & & $16(40.0)$ \\
\hline $8 / 6$ & $"$ & (alternately) & $5(12.5)$ \\
\hline $10 / 6$ & $"$ & & $1 \quad(2.5)$ \\
\hline 11 & $"$ & & $4(10.0)$ \\
\hline 12 & $"$ & & $3 \quad(7.5)$ \\
\hline 13 & $"$ & & $1 \quad(2.5)$ \\
\hline 14 & $"$ & & $1 \quad(2.5)$ \\
\hline 11 & $"$ & & $1 \quad(2.5)$ \\
\hline 10 & $"$ & & $2 \quad(5.0)$ \\
\hline
\end{tabular}

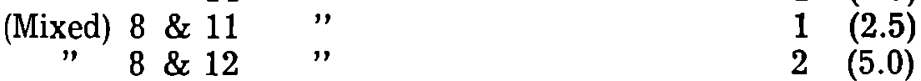

Table 7 shows the occurrence of different types of syllabic verse in individual writers and texts. The latter, as in subsequent tables, are arranged in approximately chronological order.

TABLE 7

THE INCIDENCE OF SYLLABIC VERSE IN INDIVIDUAL WRITERS AND TEXTS

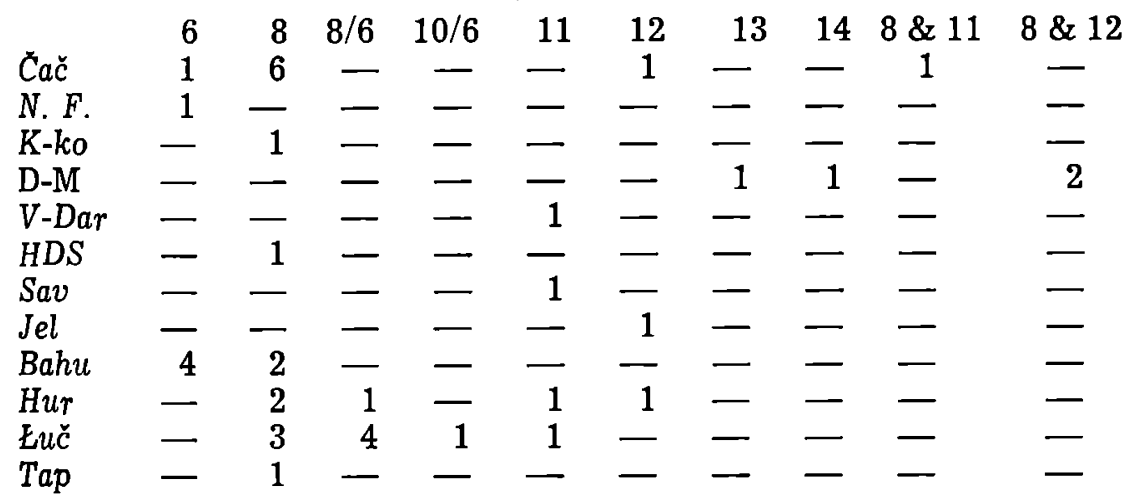


From Tables 6-7 may be observed the 19th-century poets' preference for short rather than long syllabic metres, a preference which is also reflected in the figures for the 'miscellaneous' poems which do not fit exactly any of the three 'established' types where there are over four times as many irregular short syllabic as long syllabic lines. See Tables 12-15 below.

Whilst regular syllabo-tonic metres account for only $13.9 \%$ of all the poems under consideration, there are intermittent elements of syllabo-tonic rhythm in very many verses which are, however, too inconsistent to be described as regular syllabo-tonic. Hrynčyk, for example, notes a tendency to ternary metres in Bahuševič, but in fact only 1 of his poems (Achviara) maintains a regular ternary metre (3-foot anapaests); similarly, Łučyna's poems are described as having a basically binary metre, although close analysis reveals only 3 of his poems to be regular in this respect: Karšun (4-foot iambs), and Sto dumaje Janka, viezučy drovy $\breve{u}$ horad and Nie ja piaju - narod božy (4-foot trochees). ${ }^{16}$ Another case in point is Karatynski's 40-line Ustavajma, bratcy! written in 4-stress tonic verse, but with 15 unsuccessive lines in regular 4-foot dactylic metre.

Tables 8-9 show the number of poems with the different types of syllabo-tonic metre, and their occurrence in individual writers and texts.

\section{TABLE 8}

THE INCIDENCE OF SYLLABO-TONIC METRES

Iambic Trimeter

Iambic Tetrameter / Trimeter

Iambic Tetrameter

Trochaic Tetrameter / Trimeter

Trochaic Tetrameter

Free Trochees

$\%$

$\begin{array}{rr}1 & (2.7) \\ 1 & (2.7) \\ 8 & (21.6) \\ 3 & (8.1) \\ 17 & (45.9) \\ 1 & (2.7) \\ 1 & (2.7) \\ 1 & (2.7) \\ 1 & (2.7) \\ 1 & (2.7) \\ 2 & (5.4)\end{array}$

Amphibrachic Trimeter

Amphibrachic Tetrameter / Trimeter

Amphibrachic Tetrameter

Anapaestic Dimeter / Amphibrachic Dimeter

Anapaestic Trimeter

The preponderance of trochaic metres, and tetrameters in particular, is perhaps not surprising in view of the frequency with which the trochaic cadence occurs in folk poetry. Indeed, the trochaic tetrameter was widely used by Russian imitators of popular verse in the 18 th century. ${ }^{17}$ The iambic tetrameter, however, easily the most commonly used Russian metre from the 18th century to the present day, ${ }^{18}$ finds relatively little reflection in Byelorussian 19th-century verse, apart from the three important anonymous poems in the early part of the century.

16. M. M. Hrynčyk, op. cit., pp. 136, 144.

17. B. O. Unbegaun, op. cit., pp. 32-3.

18. For example, over half Puškin's lines are in this metre. Unbegaun, op. cit., p. 21. 
TABLE 9

THE INCIDENCE OF SYLLABO-TONIC METRES IN INDIVIDUAL WRITERS AND TEXTS

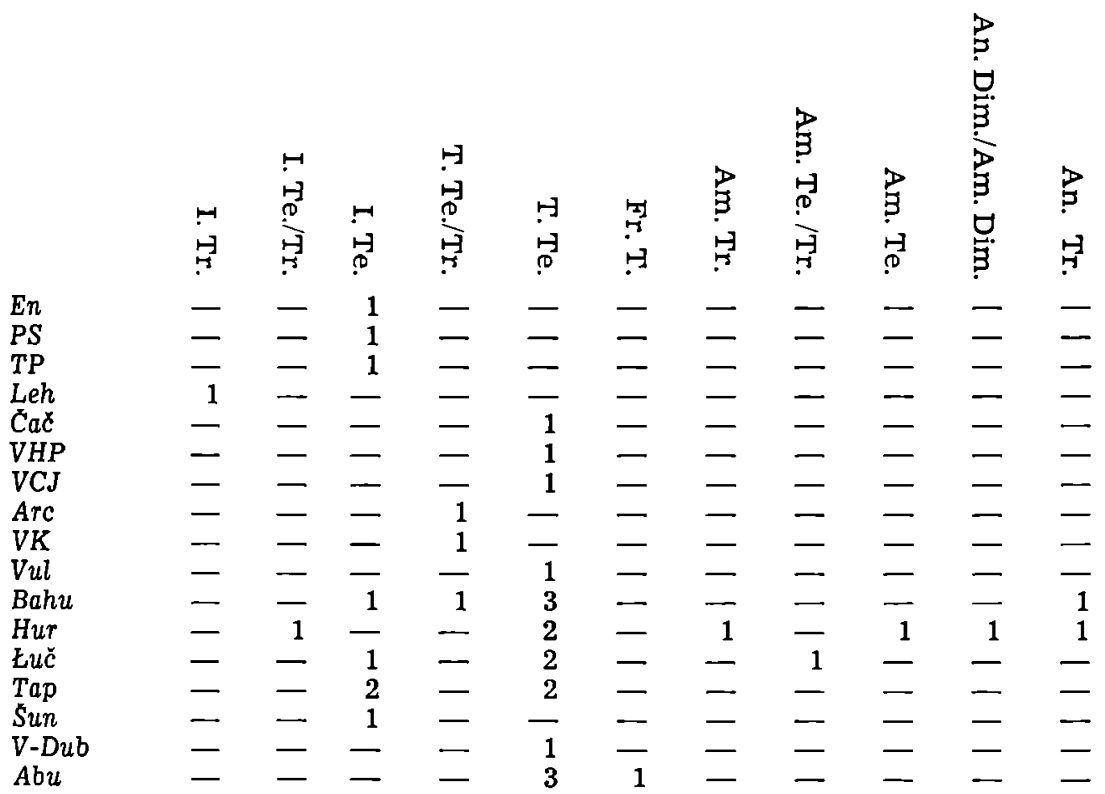

Tables 10-11 show the number of poems with the various types of tonic metre, and their occurrence in individual writers and texts.

TABLE 10

THE INCIDENCE OF TONIC VERSE

\begin{tabular}{lrr} 
& & \multicolumn{2}{c}{$\%$} \\
2-stress & 9 & $(29.0)$ \\
2-stress / 4-stress & 1 & $(3.2)$ \\
3-stress & 3 & $(9.7)$ \\
4-stress & 18 & $(58.1)$
\end{tabular}

TABLE 11

THE INCIDENCE OF TONIC VERSE IN INDIVIDUAL WRITERS

$\begin{array}{lcccr}R y p & 2 \mathrm{~S} & 2 \mathrm{~S} / 4 \mathrm{~S} & 3 \mathrm{~S} & 4 \mathrm{~S} \\ \text { VK } & - & - & 1 & - \\ \text { Bahu } & 5 & - & - & 1 \\ \text { Hur } & 4 & 1 & - & 12 \\ \text { Łč } & - & - & - & 3\end{array}$

Of the 115 miscellaneous poems which cannot be strictly classified as either syllabic, syllabo-tonic or tonic the majority (85) may be grouped according to the number of syllables, or approximate number of syllables, per line. Of these $85,42(49.4 \%)$ are in short lines 
(of up to 9 syllables), $10(11.8 \%$ ) are in long lines (of over 9 syllables) $10(11.8 \%)$ are in alternating lines, and $13(15.3 \%)$ are in a mixture of 2 or 3 kinds of syllabically organised lines. Finally, $11(12.9 \%)$, although irregular in line-length, show a tendency towards a particular length in the majority of their lines. The remaining 29 poems, which are too irregular to be classified, include 3 by Dunin-Marcinkievič (Pavinšavańnie Vojta Nauma, Viečarnicy ${ }^{19}$ and Travica brat-siastryca) and Bahuševič (Hdzie čort nie moža, tam babu pašle, Svaja ziamla and Śviñni $i$ barany), 2 by Barščeŭski (Harelica ${ }^{20}$ and Rabunki myžykoü ${ }^{21}$ and Jelski (Pan Tadeuš and Synok), and 1 each by Karatkievič (Biełaruski Dudaru), Pratasievič (Susiedčyk Haviejski) and Staŭbun (Chto $j a$ ?); all the other unclassifed poems are anonymous, ranging from extended narratives like Hutarka $\breve{u}$ karčmie to the doggerel $P^{\prime}$ janica (which lacks both metre and rhyme). ${ }^{22}$

Table 12 refers to the group of 42 miscellaneous poems with short lines which are of fixed length but without exclusively feminine endings and/or a regular pattern of stresses. Table 13 shows the occurrence of these poems in individual writers and texts.

TABLE 12

THE INCIDENCE OF MISCELLANEOUS VERSES WITH SHORT LINES

\begin{tabular}{rrrl}
6 & syllables & & \multicolumn{1}{c}{$\%$} \\
7 & $"$ & 1 & $(2.4)$ \\
8 & $"$ & 8 & $(19.0)$ \\
$6-8$ & $"$ & 5 & $(11.7)$ \\
$7-8$ & $"$ & 3 & $(7.1)$ \\
$7-9$ & $"$ & 14 & $(33.3)^{23}$ \\
$8-9$ & $"$ & 7 & $(16.7)$ \\
& & 4 & $(9.5)^{24}$
\end{tabular}

19. Hrynčyk presents a formal analysis of the line-lengths $(7,8,9,10,10 / 11$, $11,11 / 12$ and 12 syllables) in this work and shows how as 'the poem progresses through its three parts the proportion of long lines increases and that of short lines decreases. M. M. Hrynčyk, op. cit., p. 108.

20. A very disorganised verse with faint and irregular $8 / 6$ Leonine elements.

21. This narrative poem appears to find its prosodic origins in pre-syllabic folk tonic systems. That it should be 'unclassifiable' whereas Rypinski's more regular, but otherwise not dissimilar Niačyścik falls into the category of 3-stress tonic (see Table 11) underlines the difficulty of applying conventional terms to unconventional verse.

22. See n. 9.

23. 12 of the 14 poems have 7-syllable masculine and 8-syllable feminine lines.

24 . 2 of the 4 poems have 8 -syllable masculine and 9 -syllable feminine lines. 
TABLE 13

THE INCIDENCE OF MISCELLANEOUS SHORT-LINE VERSES IN INDIVIDUAL WRITERS AND TEXTS

\begin{tabular}{|c|c|c|c|c|c|c|c|}
\hline & 6 & 7 & 8 & $6-8$ & $7-8$ & $7-9$ & $8-9$ \\
\hline Bahr & - & - & - & - & - & 1 & - \\
\hline$P S N$ & - & - & - & - & 1 & - & - \\
\hline$S V B$ & - & - & - & - & - & 1 & - \\
\hline$B K$ & - & - & - & - & 1 & - & - \\
\hline Ryp & - & - & - & - & 1 & - & - \\
\hline Cać & - & 8 & - & - & - & - & - \\
\hline$D-M$ & - & - & - & - & 1 & - & - \\
\hline V-Dar & 一 & - & 1 & - & 1 & 一 & 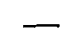 \\
\hline Syr & - & - & - & - & 1 & - & - \\
\hline$H K N$ & - & - & - & 一 & 1 & - & 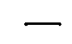 \\
\hline$H K A$ & - & - & - & - & 一 & 1 & - \\
\hline$V K$ & 1 & - & - & 一 & - & - & - \\
\hline$T-k i$ & - & - & - & 1 & - & - & - \\
\hline Pčy & - & - & - & 一 & 1 & - & - \\
\hline$N S$ & - & - & - & 1 & - & 2 & 1 \\
\hline$P E$ & - & - & - & - & 1 & - & 一 \\
\hline$S-Z$ & - & - & 1 & - & - & 1 & 1 \\
\hline Hor & - & - & - & 一 & 一 & - & 1 \\
\hline Jel & - & - & - & - & - & 1 & - \\
\hline Mih & - & - & - & 一 & 1 & - & - \\
\hline Bahu & - & - & 2 & 1 & 2 & - & 1 \\
\hline Hur & - & - & - & - & 1 & - & - \\
\hline Tam & - & - & - & - & 1 & - & - \\
\hline$V-D u b$ & - & - & 1 & - & 一 & - & - \\
\hline
\end{tabular}

Table 14 refers to the group of 10 miscellaneous poems with long lines which are of fixed length but without exclusively feminine endings and/or a regular pattern of stresses. Table 15 shows the occurrence of these poems in individual writers and texts.

TABLE 14

THE INCIDENCE OF MISCELLANEOUS VERSES WITH LONG LINES

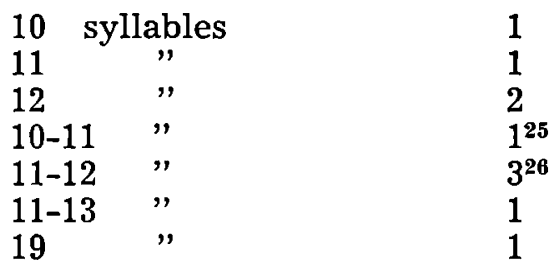

25. This poem has 10-syllable masculine and 11-syllable feminine lines.

26. 1 of these 3 poems has 11-syllable masculine and 12-syllable feminine lines. 
TABLE 15

THE INCIDENCE OF MISCELLANEOUS LONG-LINE VERSES IN INDIVIDUAL WRITERS AND TEXTS

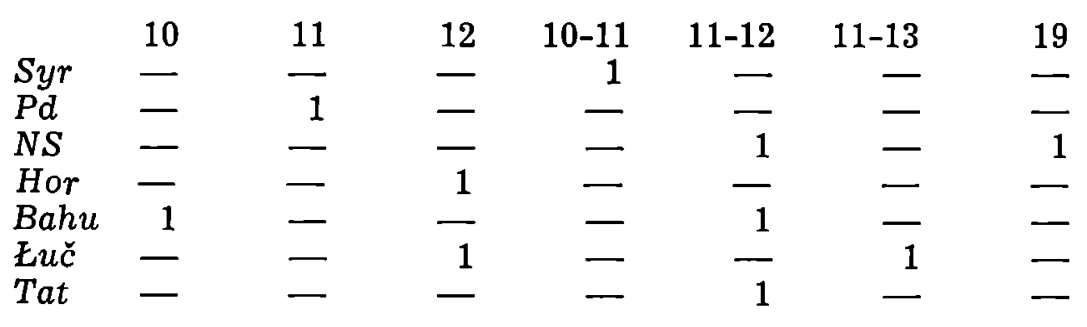

Tables 16-17 refer to the group of 10 miscellaneous verses with alternating lines, and show their occurrence in individual writers and texts.

TABLE 16

THE INCIDENCE OF MISCELLANEOUS VERSES WITH ALTERNATING LINES

$\begin{array}{rcl}6 / 5 & \text { syllables } & 1 \\ 7 / 5 & " & 1 \\ 7 / 6 & " & 2^{27} \\ 8 / 6 & " & 3^{28} \\ 8 / 7 & " & 1 \\ 9 / 7 & " & 1 \\ 10 / 8 & " & 1\end{array}$

TABLE 17

THE INCIDENCE OF MISCELLANEOUS VERSES WITH ALTERNATING LINES IN INDIVIDUAL WRITERS AND TEXTS

$\begin{array}{lccccccc} & 6 / 5 & 7 / 5 & 7 / 6 & 8 / 6 & 8 / 7 & 9 / 7 & 10 / 8 \\ \text { Cač } & 1 & - & 2 & 2 & 1 & - & - \\ P £ & - & - & - & 1 & - & - & - \\ \text { Hur } & - & 1 & - & - & - & 1 & 1\end{array}$

Tables 18-19 refer to the group of 13 miscellaneous verses with mixed but not alternating lines, and show their occurrence in individual writers and texts.

27. The $7 / 6$ pair of alternating lines is arguably a descendant of the classical 13-syllable line in syllabic poetry.

28. See the section on Leonine verse above. 
TABLE 18

THE INCIDENCE OF MISCELLANEOUS VERSES WITH MIXED BUT NOT ALTERNATING LINES

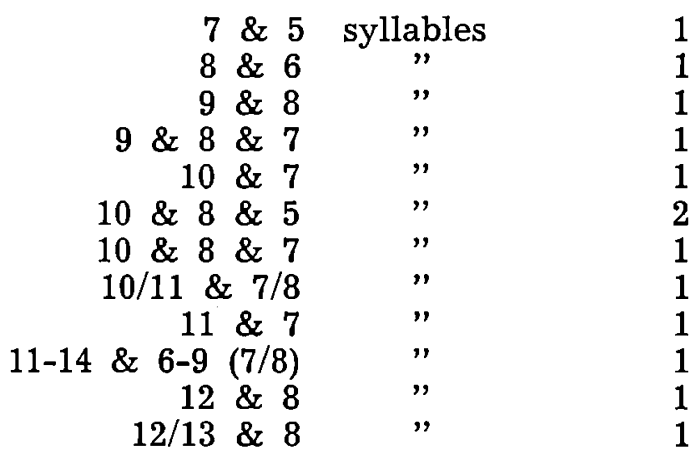

TABLE 19

THE INCIDENCE OF MISCELLANEOUS VERSES WITH MIXED LINES IN INDIVIDUAL WRITERS AND TEXTS

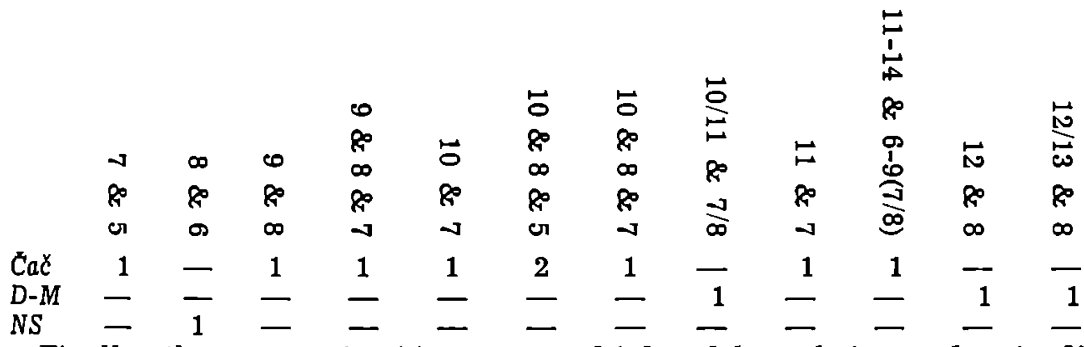

Finally, there remain 11 poems which, although irregular in linelength, show a tendency towards a particular length in the majority of their lines. Barščeŭski's Ach čym ža tvaja, dzievańka, hałoŭka zaniata? $(14,14,8,8,6,14,14,6,7,5)^{29}$ has a definite pattern which may be compared with 3 of Cačot's verses: Oj haspadynia and $\mathrm{Na}$ što nam dym vyjedaje očy $(10,10,8,8,5)$, and $U$ lesie takujeć cieciaruk $(9,9$, $8,8,5) .{ }^{30}$ The other 10 are unpatterned. Tables 20-21 show the number of poems inclined to but not adhering rigidly to various line-lengths, and their occurrence in individual writers and texts.

TABLE 20

THE INCIDENCE OF MISCELLANEOUS VERSES INCLINED TO CERTAIN LINE-LENGTHS

$\begin{array}{rcc}7 & \text { syllables } & 1 \\ 8 & " & 2 \\ 8-9 & " & 4 \\ 11 & " & 1 \\ 11 / 12 \& 7 / 8 & " & 1 \\ 12-13 & , & 1\end{array}$

29. Hrynčyk describes the poem as 14 -syllable syllabic verse. M. M. Hrynčyk, op. cit., p. 77.

30. See Tables 18-19. Cačot is particularly inclined to patterning by variation in line-length. For example, $14(50 \%)$ of his Pieśni make use of this technique. 
TABLE 21

THE INCIDENCE OF MISCELLANEOUS VERSES INCLINED TO CERTAIN LINE-LENGTHS IN INDIVIDUAL WRITERS AND TEXTS.31

\begin{tabular}{|c|c|c|c|c|c|c|}
\hline & 7 & 8 & $8-9$ & 11 & $11 / 12 \& 7 / 8$ & $12-13$ \\
\hline Čač & - & - & - & 1 & - & - \\
\hline$D-M$ & 一 & 一 & 一 & 一 & 1 & 一 \\
\hline$M H$ & - & - & 1 & - & - & - \\
\hline$N S$ & 1 & 1 & - & - & - & - \\
\hline Btu & - & - & 2 & 一 & - & - \\
\hline$H D s a S$ & - & - & 一 & - & - & 1 \\
\hline$H S D$ & 一 & 1 & - & 一 & 一 & - \\
\hline$H P$ & - & - & 1 & 一 & 一 & - \\
\hline
\end{tabular}

The author of the present study has deliberately limited to a bare minimum conclusions drawn from the statistical material, tempting though it is to embark on the extensive and fascinating exercise of drawing patterns of development, particularly with reference to the irregular and intermediate forms which play so great a role in Byelorussian 19th-century poetry. Immense possibilities for further analysis remain, both on the basis of the material presented here and also from the investigation of the numerous aspects of the subject which still await scholarly attention. It is hoped the present study may serve as a starting-point for further research. Until this work is performed the history and development of Byelorussian versification will remain one of the least known aspects of Slavonic cultural history.

31. Tables 20-21 should be considered in conjunction with Tables 6, 7, 12-15. 